\title{
Energy efficiency in multi-story buildings
}

\author{
Anastasiia Staritcyna ${ }^{1,}{ }^{,}$,Eric Pollock ${ }^{2}$,Ekaterina Sokolova ${ }^{3}$ and Elena Martynenko ${ }^{4}$ \\ ${ }^{2}$ Helsinki Metropolia University of Applied Sciences, Vanha maantie 6, 02650 Espoo, Finland \\ ${ }^{1,3,4}$ St. Petersburg State Polytechnical University, Politekhnicheskaya, 29, Saint-Petersburg, 195251, \\ Russia
}

\begin{abstract}
In this project a research on energy efficiency of Malta house was provided, it is a residential multi-story building in Helsinki, Jätkäsaari area. This project describes introduction with a new heating system for residential dwellings, which uses only heated air. To maintain air temperature in comfort level heat recovery and district heating is used in the same system. The task was to research efficacy of the enclosure structures. For research the $3 \mathrm{D}$ model has been created in the program the Revit 2015 and Lumion 13. Thermotechnical calculation for three types of a design has been executed in the program U-value.net.
\end{abstract}

\section{Introduction}

Energy efficiency problem gets more actual due to prices rise for energy resources, as well as the reduction of non-renewable energy sources. In addition, to that we should take into account the amount of carbon dioxide are increasing in the atmosphere. Human being has to reduce the power consumption to a minimum value $[1,2]$. One of the areas to reduce energy consumption is housing, which consumes approximately 30 to $40 \%$ of all energy resources. While the existing old buildings consume from 200 to 400 [kWh / ( $\mathrm{m}^{2}$ • Year)] thermal energy for heating, buildings of the future generation would be expected to consume from [20 to $50 \mathrm{kWh} /\left(\mathrm{m}^{2}\right.$ - Year)] [3]. Some European countries already have similar standards of energy consumption. Solution to this problem is the construction of buildings with zero energy consumption, or close to zero [4]. Such buildings do not have heating expenses because the heat losses are fulfilled by renewable energy sources, as well as household and solar energy [5].

The heat camera was used to monitor thermal radiation from building's surfaces, such as exterior walls, windows and floors, to estimate thermal resistance of the house. For testing the efficiency of the heating system, the Wirepas (Wireless building monitoring) system was used in a single apartment.

Minimal requirements set for multi-storey buildings in Finland are described in the National Building Code of Finland. Part D2 of the code addresses the requirements aimed for the indoor environment, ventilation and air conditioning of residential spaces [6].

\footnotetext{
*Corresponding author: a.staritsyna@mail.ru
} 
Table 1. Guideline values for room temperatures for different room types during the heating season for spaces where the room temperature design value is not $21{ }^{\circ} \mathrm{C}$

\begin{tabular}{|l|l|}
\hline Room type & $\begin{array}{l}\text { Room temperature } \\
{\left[{ }^{\circ} \mathbf{C}\right]}\end{array}$ \\
\hline Stair well & 17 \\
\hline Bathroom, washroom & 22 \\
\hline Drying room & 24 \\
\hline Room type & $\begin{array}{l}\text { Room temperature } \\
{\left[{ }^{\circ} \mathrm{C}\right]}\end{array}$ \\
\hline Shop & 18 \\
$\bullet$ fixed work station in a shop & 21 \\
\hline Gymnasium & 18 \\
\hline
\end{tabular}

When using the guideline values the level of comfort of adjoining rooms must be ensured.

Table 2. Air flow, air movement and sound.

\begin{tabular}{|c|c|c|c|c|c|c|}
\hline 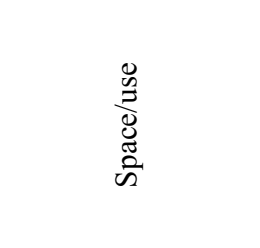 & 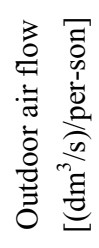 & 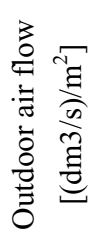 & 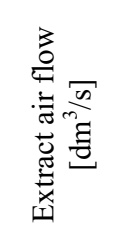 & 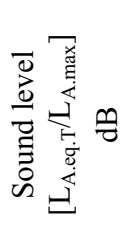 & 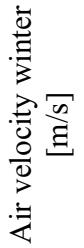 & 吕 \\
\hline Dwe-lling spaces: & 6 & & & & & \\
\hline Dwe-lling rooms & & 0.5 & & $28 / 33 *$ & 0.20 & ${ }^{\circ} \mathrm{C} 1$ regula-tion \\
\hline $\begin{array}{c}\text { Kit-chen } \\
\text { impro-vement of } \\
\text { occu-pancy period }\end{array}$ & & $\begin{array}{l}\# \mathrm{~S} \\
\# \mathrm{~S}\end{array}$ & $\begin{array}{c}8 \# \mathrm{~A} \\
25\end{array}$ & $\begin{array}{l}33 / 38 * \\
33 / 38\end{array}$ & 0.20 & ${ }^{\circ} \mathrm{C} 1$ regula-tion \\
\hline $\begin{array}{l}\text { Cloak room, store- } \\
\text { room }\end{array}$ & & $\# \mathrm{~S}$ & 3 & $33 / 38$ & 0.20 & \\
\hline Bathroom & & $\# \mathrm{~S}$ & $10 \# \mathrm{~B}$ & $38 / 43$ & 0.20 & \\
\hline $\begin{array}{l}\text { Impro-vement of } \\
\text { occu-pancy period }\end{array}$ & & $\# \mathrm{~S}$ & 15 & $38 / 43$ & 0.20 & \\
\hline Toilet & & $\# \mathrm{~S}$ & 7 \#B & $33 / 38$ & & \\
\hline $\begin{array}{l}\text { impro-vement of } \\
\text { occu-pancy period }\end{array}$ & & $\# \mathrm{~S}$ & 10 & $33 / 38$ & & \\
\hline Utility room & & $\# \mathrm{~S}$ & 8 & $33 / 38$ & 0.30 & \\
\hline $\begin{array}{l}\text { Impro-vement of } \\
\text { occu-pancy period }\end{array}$ & & $\# \mathrm{~S}$ & 15 & $33 / 38$ & 0.30 & \\
\hline Sauna in the flat & & $2 \# \mathrm{C}$ & $2 / \mathrm{m}^{2} \# \mathrm{C}$ & $33 / 38$ & & \\
\hline Com-mon spaces: & & & & & & \\
\hline
\end{tabular}




\begin{tabular}{|c|c|c|c|c|l|l|}
\hline Stair-well & & $\begin{array}{c}0.5 \\
1 / \mathrm{h}\end{array}$ & $0.5 \mathrm{l} / \mathrm{h}$ & $38 / 43$ & & \\
\hline Store-rooms & 0.35 & $0.35 / \mathrm{m}^{2}$ & $43 / 48$ & & \\
\hline $\begin{array}{c}\text { Cold cellar (also } \\
\text { cold stores in apart- } \\
\text { ments if area is }> \\
4 \mathrm{~m}^{2} \text { ) }\end{array}$ & & 0.2 & $0.2 / \mathrm{m}^{2}$ & $43 / 48$ & & \\
\hline $\begin{array}{c}\text { Dres-sing room } \\
\text { Wash-room }\end{array}$ & 2 & $2 / \mathrm{m}^{2}$ & $33 / 38$ & 0.20 & \\
\hline $\begin{array}{c}\text { Hot room in sauna } \\
\text { (n) }\end{array}$ & 2 & $2 / \mathrm{m}^{2}$ & $33 / 38$ & $43 / 48$ & 0.20 & \\
\hline $\begin{array}{c}\text { Laun-dry room in } \\
\text { the buil-ding }\end{array}$ & 1 & $1 / \mathrm{m}^{2}$ & $43 / 48$ & & \\
\hline $\begin{array}{c}\text { Drying room } \\
\text { Hobby room, club } \\
\text { room }\end{array}$ & $1 \# \mathrm{E}$ & $2 / \mathrm{m}^{2} \# \mathrm{E}$ & $33 / 38$ & 0.20 & \\
\hline
\end{tabular}

Addresses the guidelines for air flow, air movement and sound levels in residential spaces. If there are insufficient grounds for the dimensioning of the air flows, according to number of occupants, the surface area is used for the dimensioning. Extract air flows in large dwellings are generally designed to be higher than the guideline values so that the outdoor air flow for each space is in accordance with the guideline value. The air change coefficient of the space must be at least 0.5 of the total volume per hour. Part D3 of the building code discusses the requirements and guidelines of energy efficiencies. The code sets out the specific values to be used while calculating the efficiencies. The code considers total energy consumption, air-tightness of the building shell, heat losses, ventilation system efficiency and needed heating power. New apartment buildings are required to have an Eratio $\left(\mathrm{kWh} / \mathrm{M}^{\wedge} 2\right.$ per year) of no more than 130 [7].

\section{Literature review and formulation of research problems}

Great contribution to the possible solutions of energy saving and energy efficiency was made by the following researchers: D.I. Markov, A.O. Pogonin, A.S. Gorshkov, D.V. Nemova, N.I. Vatin and many others.

Markov's article describes the experience of the design and construction of energy efficient buildings, talks about the principles of formation for such buildings (architectural, urban planning and engineering solutions energy saving). The present work focuses on the experience of designing «passive» houses in Darmstadt. It describes the experience of designing, a model of a residential complex of energy efficient buildings for the conditions of the Gatchina District, Leningrad Region, architectural planning, design, engineering solutions of the complex and technologies of renewable energy in this model [8-12]. 
In this article Pogonin considers the peculiarities of residential buildings stand-alone type of renewable energy, analyzes historical and contemporary experience of energyefficient housing and cites, the example of a pilot project of autonomous energy-efficient residential unit [13].

The article A.S. Gorshkov, D.V. Nemova, N.I. Vatin in conceptual form is considered the major architectural and planning, three-dimensional and constructive solutions to save energy and ensuring energy efficiency of residential buildings. In this work was a comparative analysis of thermal costs energy for heating during the heating season for a private single-family house designed, according to the minimally acceptable level of regulatory requirements for thermal insulation standards in Russia and Finland. It has been proven that the determining factors for low-level consumption in buildings thermal energy for heating are: a high level of thermal insulation of external building envelope (walls, windows, roofs, etc.), tightness of the outer shell of the building and its compactness (low coefficient of compactness) [14-20].

Despite the large number of publications, that discusses advantages of consumption with zero and low power consumption, it has not yet been developed in such construction. The main objective of this work is to provide avoidance which shows modern Finland energy efficiency issues.

\section{The object of work}

Brand new building with low energy consumption was built on the territory of Helsinki, Jätkäsaari area. The building is equipped with modern energy-saving technologies and equipment that meets the highest international trends of construction Passive House type. Malta building uses decentralized forced air heating and ventilation system [21-28].

Throughout the operational phase was providing energy monitoring, evaluation of thermal characteristics, the determination of actual performance energy consumption. To provide this, the building was equipped with Wirepas wireless building monitoring system and heat camera.

\section{Indoor environment quality}

For the Malta building we used the Wirepas wireless building monitoring system. This system uses a closed wireless network to collect data from nodes placed around the building. This system can be used to monitor many aspects of the indoor environmental quality, for example temperature, relative humidity, carbon dioxide, and luminance. This information is uploaded to a wireless server and can be monitored in real time from a computer or mobile device. For our short time of monitoring we placed four sensors in apt. A21. This allowed us to observe both the building HVAC system and the Wirepas system in action. The time and scale allowed for our time and monitoring was not enough to get a good overview of the indoor environment, but the apartment which we did monitor seemed quite good. The Wirepas system is quite sensitive, showing quite small variations in the carbon dioxide and relative humidity. 

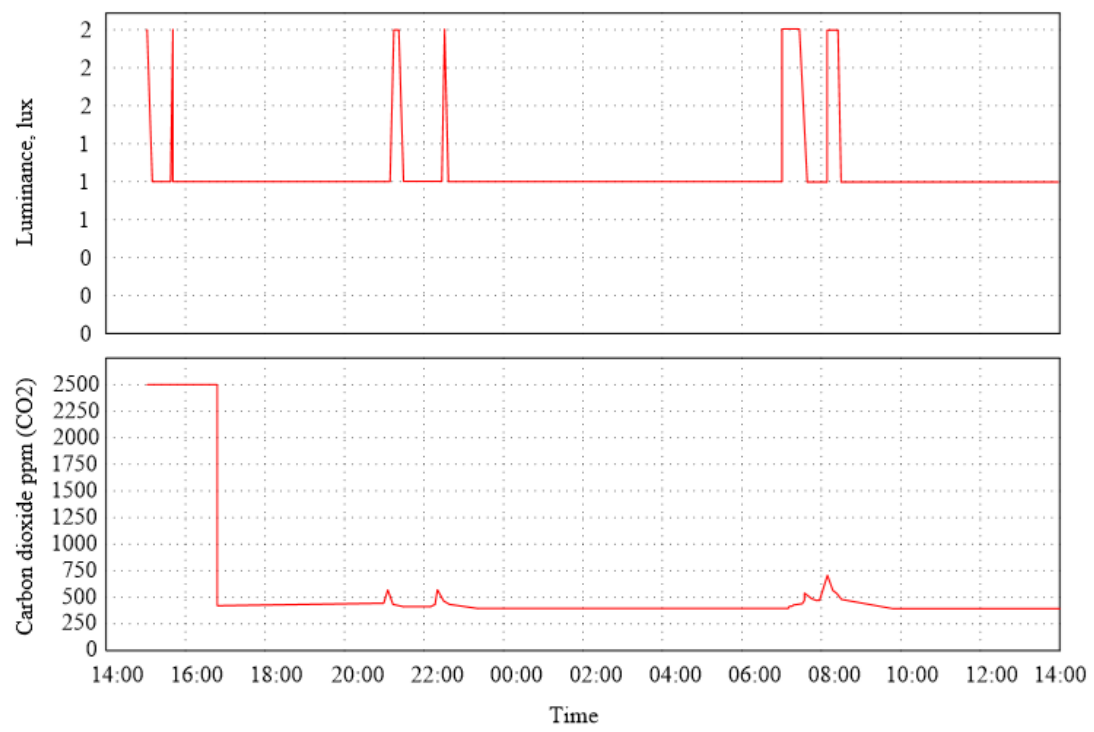

Fig. 1. Carbon dioxide and luminance values.

For example in the above data collected in the WC of apt. A21 we can see that the occupant used the WC five times during the monitoring period. At each occurrence of luminance, or use, we can see a small spike in the carbon dioxide corresponding to it. This however drops again as soon as the occupant left. This tells us that the ventilation system is working very well to circulate the air and keep it fresh. Another interesting data point we observed was from the sensor we left in place directly in front of the supply air vent in the main living space.
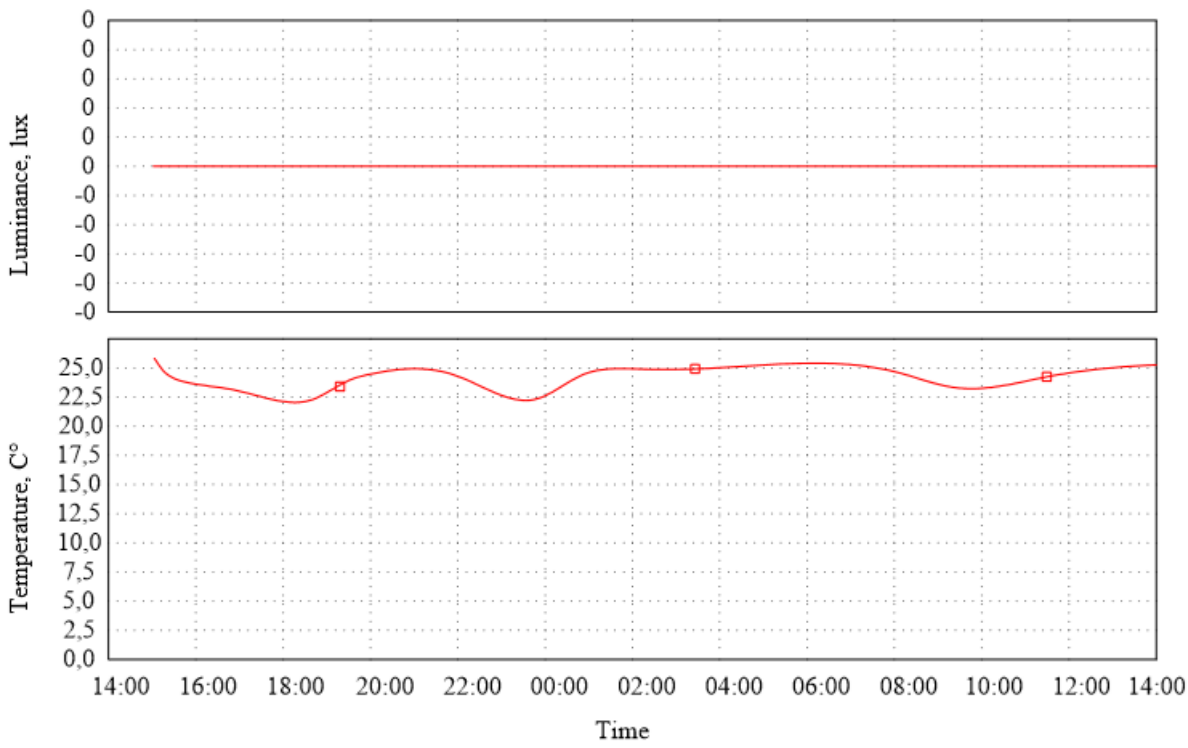

Fig. 2. Temperature and luminance values. 
Here in the temperature data taken from $30 \mathrm{~cm}$ in front of the living room supply air vent we can see quite large temperature changes over the course of the evening and night. However, when we examine the data from sensors which were farther out into the space we find something quite different.
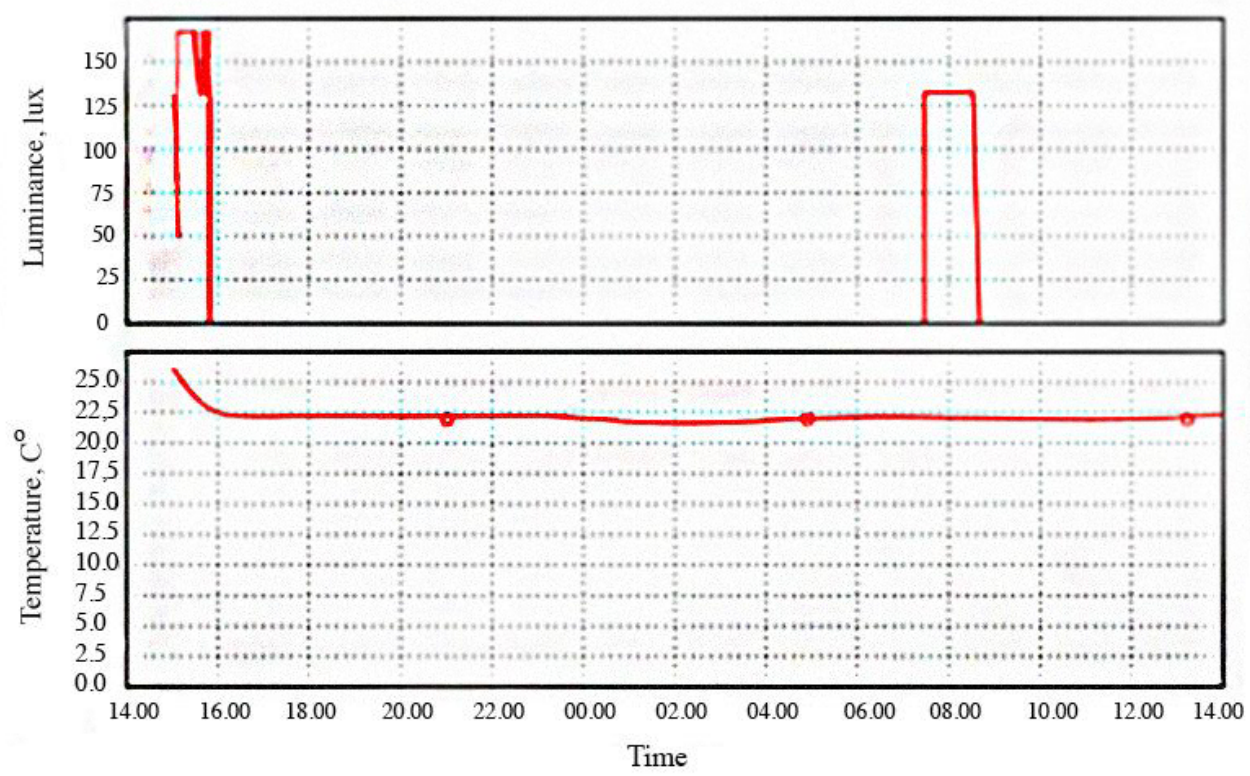

Fig. 3. Temperature and luminance values.

Here farther out in the room we notice that the temperature remains quite steady without major fluctuations in temperature. From this we determine that the system works quite well at reading the temperature of the room and responding in an acceptable time to avoid fluctuations.

In this exercise we experienced two main challenges. The first was a lack of available data, due to the limited time and scope we had available to us we were not able to make any broad range conclusions about the building as a whole. This however would be quite simple to fix. A more in depth study over a longer time would give much more relevant data. The second challenge we experienced was in setting up the Wirepas system. The system itself is quite intelligent, it actively searches for connections as each node is turned on, and if a connection is lost it will seek a new connection back to the main hub, scanning the nodes near it for an open connection. However since this process is automated, there is nothing that we can do if one node fails to work. We experienced some difficulty in starting to set up the system, struggling to achieve the first connections. However it must be said that once the network is up and running, there were no difficulties and the data was easy to collect and compare using Java script software.

\section{Examples}

The most weak and vulnerable sections of the building, which often formed "thermal bridges" are the following:

-joints of foundation walls to the floor of the first floor;

- joints of foundation walls with bearing exterior walls of the building;

-joints external load-bearing walls with a roof; 
-angles of the exterior walls;

-window openings;

-doorways;

-balcony slabs;

- architectural elements of the building;

-any site of attachment of various structural parts to the building.

Let's have a look at the different examples of thermal bridges in case of Malta.

1.Problem with doorways.

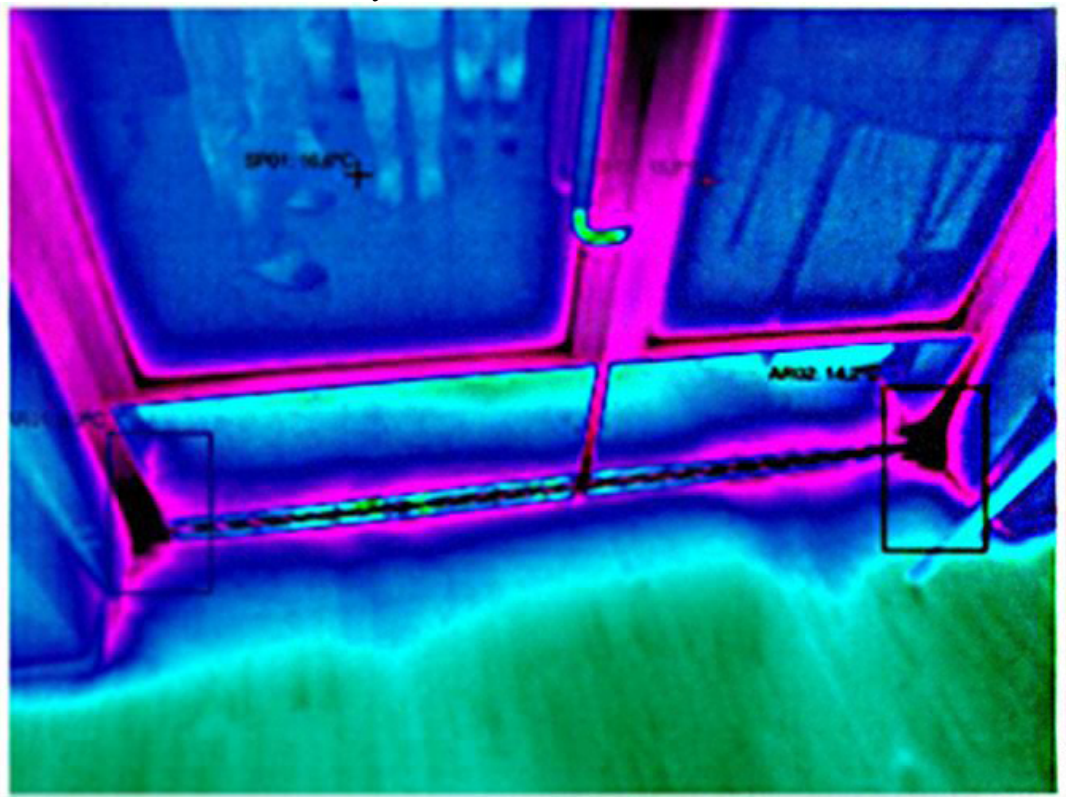

Fig. 4. Cold bridges thru door.

Normal wear possibly has caused damage to the weather stripping seals on the doors. These should be inspected and if necessary replaced.

Some spaces require maintenance.

2.Problem with the construction (Fig. 5) 


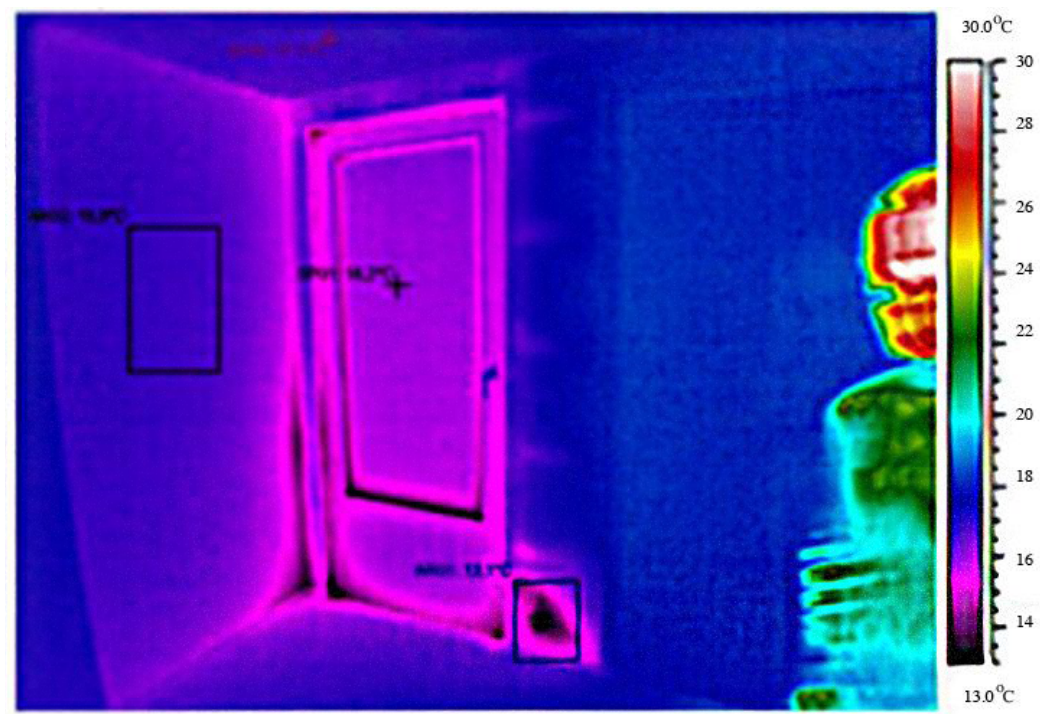

Fig. 5. Cold bridges thru wall and door.

Possible empty space or error during the construction process. Unknown cause which requires further inspection.

\section{Issues}

There are some problems which should be pointed out. First of all, the frame in figure has faulty installation and there is high heat loss around the frame. Second of all, on the bottom of the door is a crack between door surface and frame. In addition, in most of door that was inspected team found issues with locks. Their temperature is too low, what makes them cold bridges. (Fig. 6, 7)

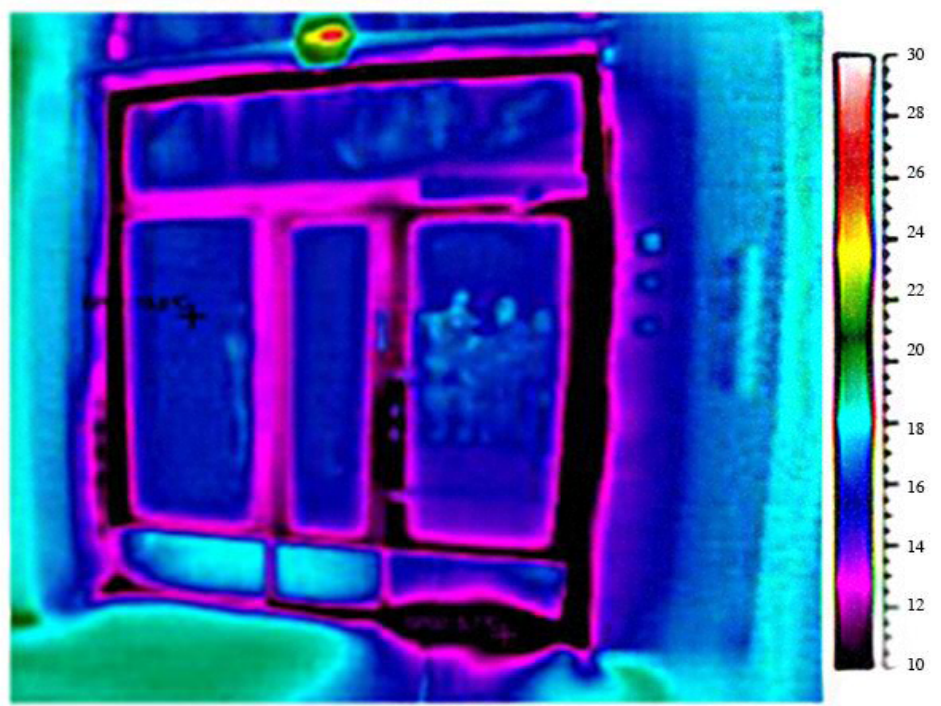

Fig. 6. Cold bridges thru door frame. 
Next figure represents issue with seal which might be worn off or faulty installation during construction process.
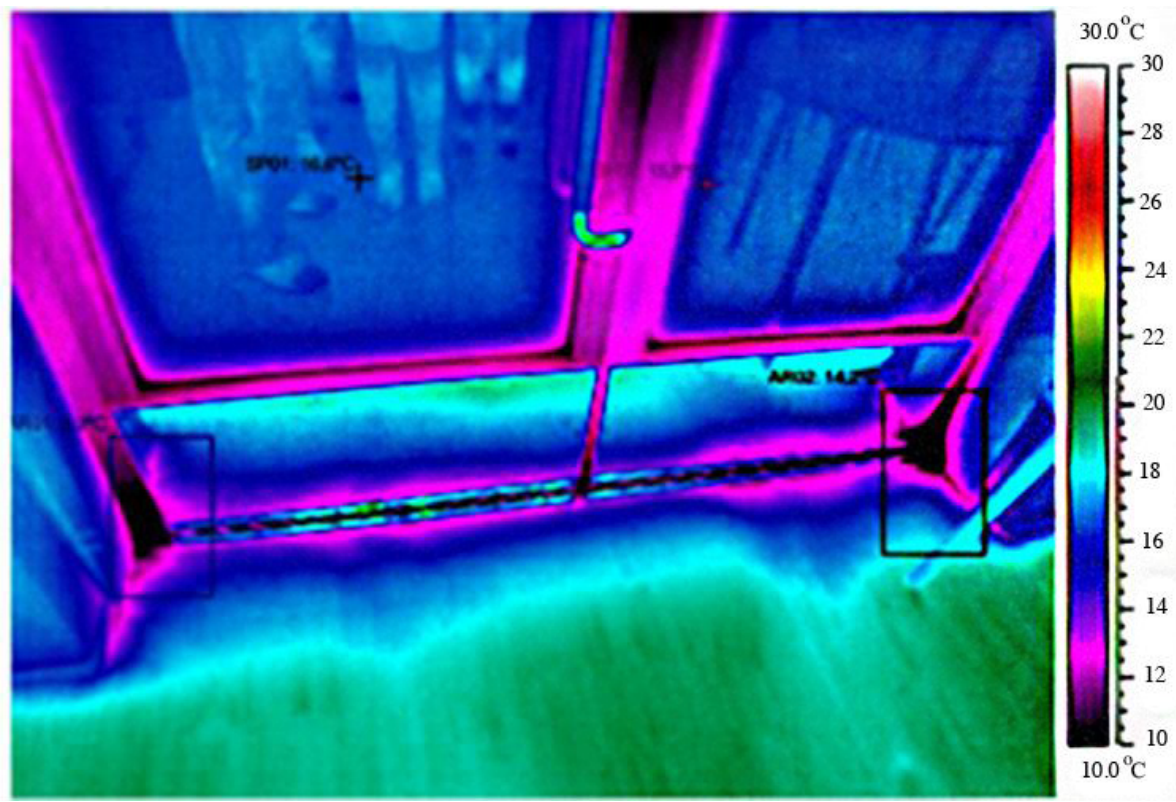

Fig. 7. Cold bridges thru door frame.

Another issue within corners of front door is shown in figure. In these spaces temperature is too low which indicates mechanical wear or faulty installation. However, mechanical damage is likely in this situation.

\section{Thermomechanical calculation of the multilayered enclosure structure u-value.net}

Design conditions and heat energy parameters of the buildings for the climatic conditions of Helsinki, Finland presented at the table 3.

Table 3. The design conditions.

\begin{tabular}{|l|c|c|}
\hline The characteristics & Unit of measure & Value \\
\hline Temperature of inside air & ${ }^{\circ} \mathrm{C}$ & 20 \\
\hline Temperature of outside air & ${ }^{\circ} \mathrm{C}$ & -7 \\
\hline Humidity of inside air & $\%$ & 50 \\
\hline Humidity of outside air & $\%$ & 80 \\
\hline
\end{tabular}

According to initial data, let's execute thermal calculation of the three types of multilayered enclosure structure.

For research the following parameters of the enclosure structures have been taken for achievement of thermal transmission coefficient value $U=0,23$. 
Table 4. Structures of walls and its characteristic

\begin{tabular}{|c|c|c|c|c|}
\hline $\begin{array}{l}\text { Type of } \\
\text { structure }\end{array}$ & Structures of walls & $\lambda, \mathbf{W} / \mathbf{m K}$ & $\rho, \mathrm{kg} / \mathrm{m} 3$ & $\delta, \mathbf{m m}$ \\
\hline & Concrete & 2.0 & 2400 & 500 \\
\hline \multirow[t]{4}{*}{ Type I } & Foam polystyrene URSA XPS & 0.033 & 35 & 120 \\
\hline & Air (ventilated layer) & 0.024 & 0,001 & 30 \\
\hline & Granite tile & 1.5 & 2600 & 12 \\
\hline & Brick & 0.960 & 2000 & 250 \\
\hline $\begin{array}{c}\text { Type of } \\
\text { structure }\end{array}$ & Structures of walls & $\lambda, \mathbf{W} / \mathbf{m K}$ & $\rho, \mathrm{kg} / \mathrm{m} 3$ & $\boldsymbol{\delta}, \mathrm{mm}$ \\
\hline \multirow[t]{4}{*}{ Type II } & Rock wool facade insulation & 0.035 & 100 & 150 \\
\hline & Air (ventilated layer) & 0.024 & 0,001 & 30 \\
\hline & Granite tile & 1.5 & 2600 & 12 \\
\hline & Light weight concrete & 1.3 & 1800 & 300 \\
\hline \multirow[t]{3}{*}{ Type III } & Polyurethane foam MUSTOVO & 0.022 & 50 & 200 \\
\hline & Air (ventilated layer) & 0.024 & 0,001 & 30 \\
\hline & Granite tile & 1.5 & 2600 & 12 \\
\hline
\end{tabular}

The following is a report on thermal calculations of the first type of the wall (fig. 8-11).

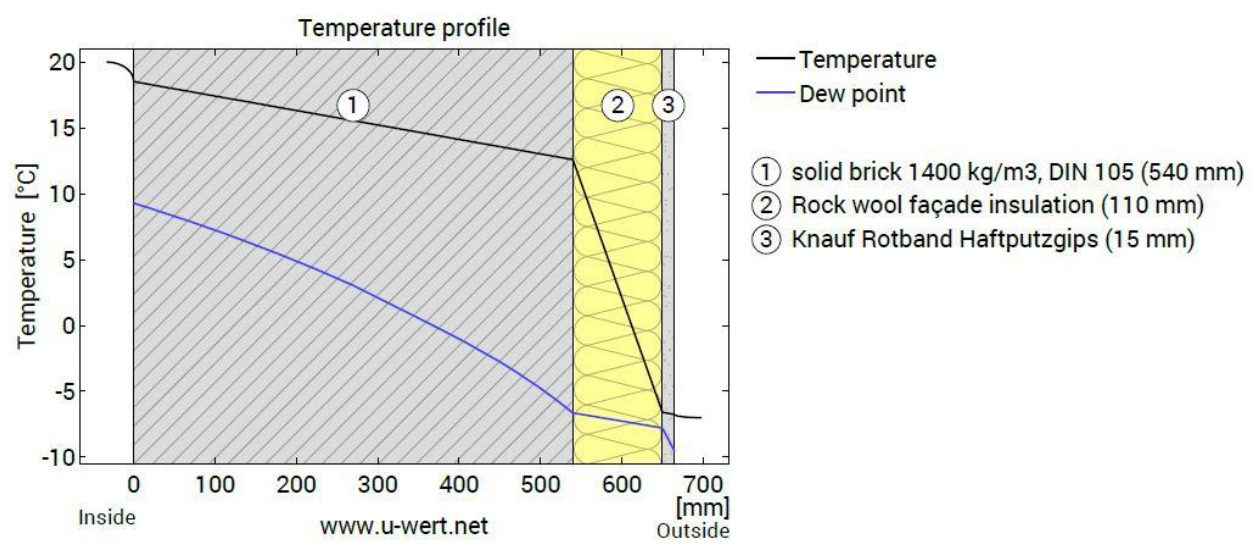

Fig. 8. Temperature gradient. Condensing zone.

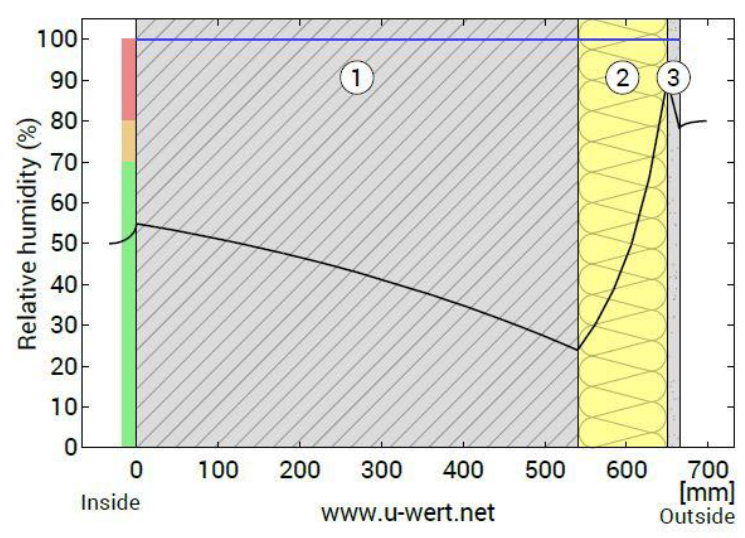
— Relative humidity (\%)
— saturation point
(1) solid brick $1400 \mathrm{~kg} / \mathrm{m} 3$, DIN $105(540 \mathrm{~mm})$
(2) Rock wool façade insulation $(110 \mathrm{~mm})$
(3) Knauf Rotband Haftputzgips ( $15 \mathrm{~mm}$ )


Fig. 9. Humidity schedule.

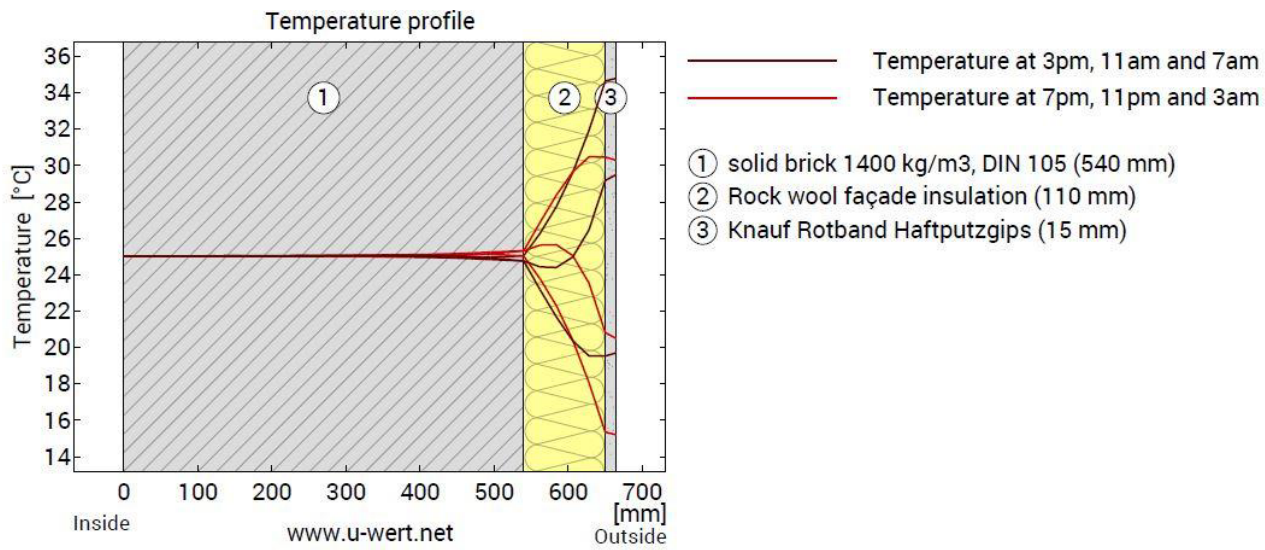

Fig. 10. Temperature schedule.

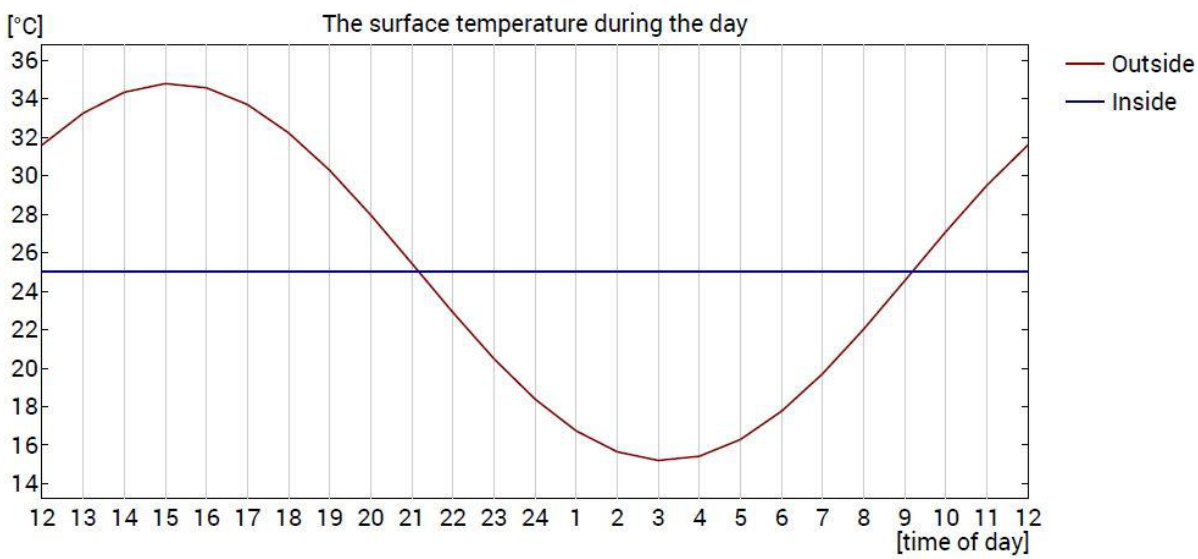

Fig. 11. The surface temperature during the day.

The report on thermal calculations of the second type of the wall (fig.12-15).

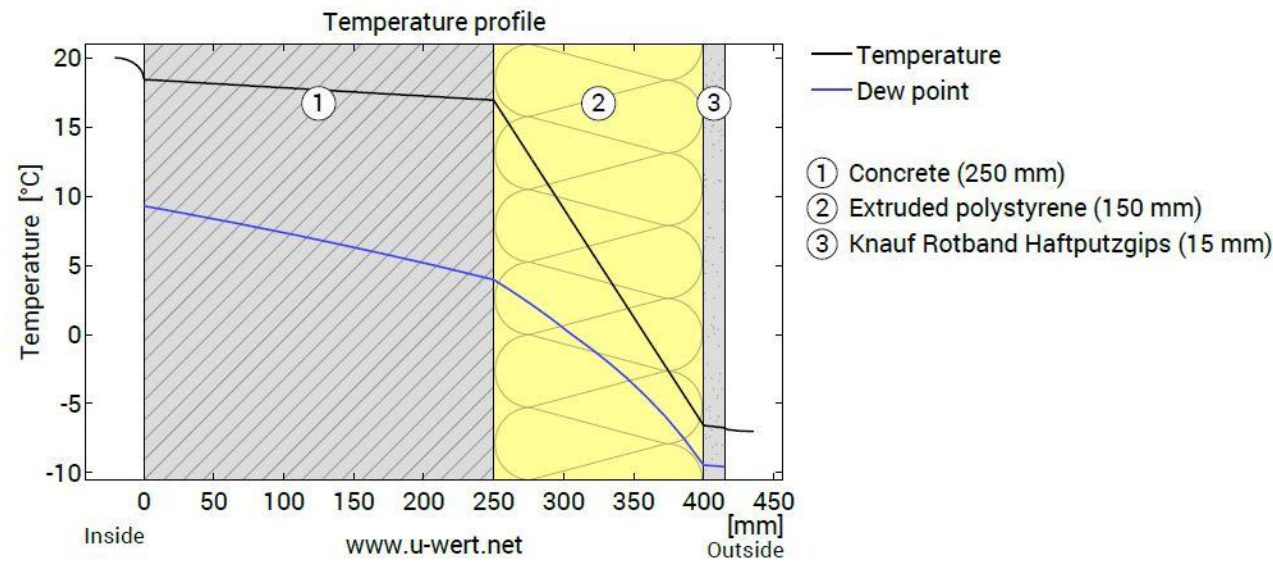

Fig. 12. Temperature gradient. Condensing zone. 

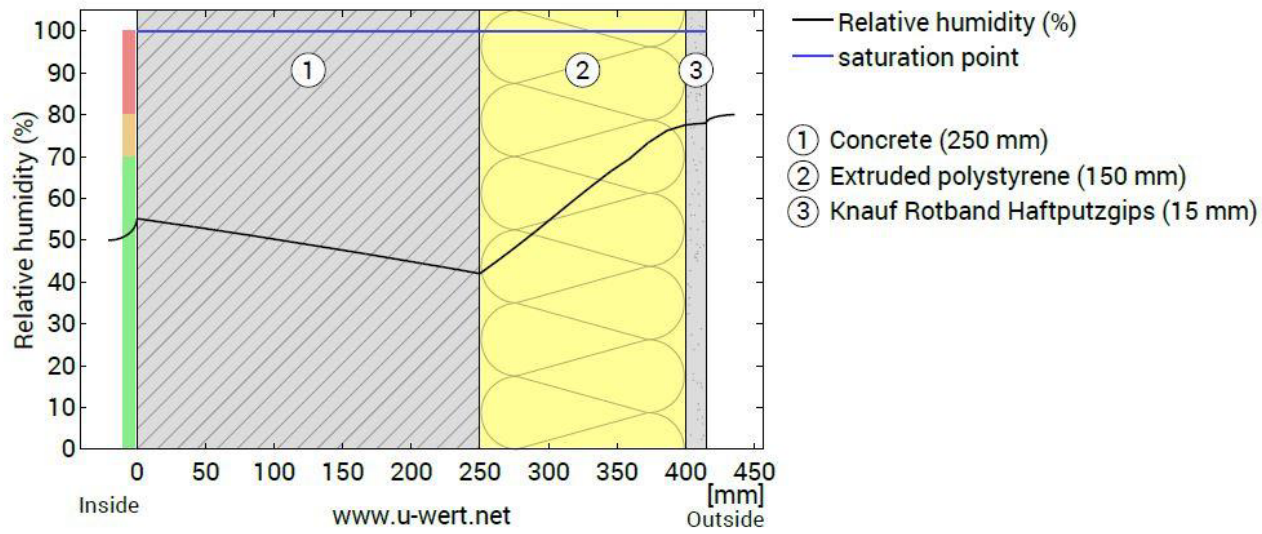

Fig. 13. Humidity schedule.

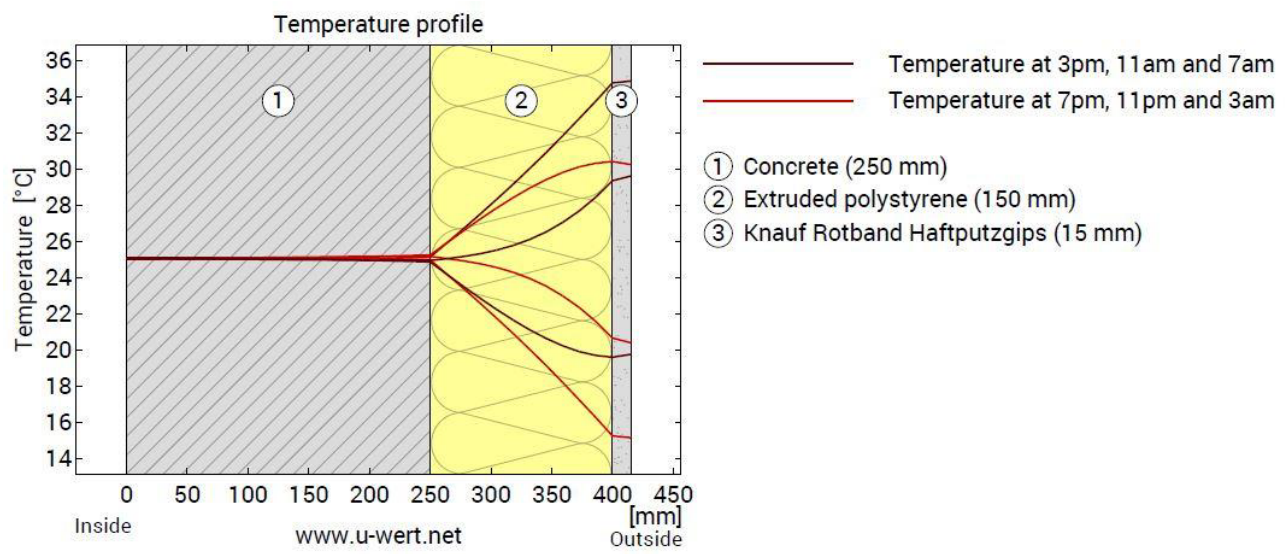

Fig. 14. Temperature schedule.

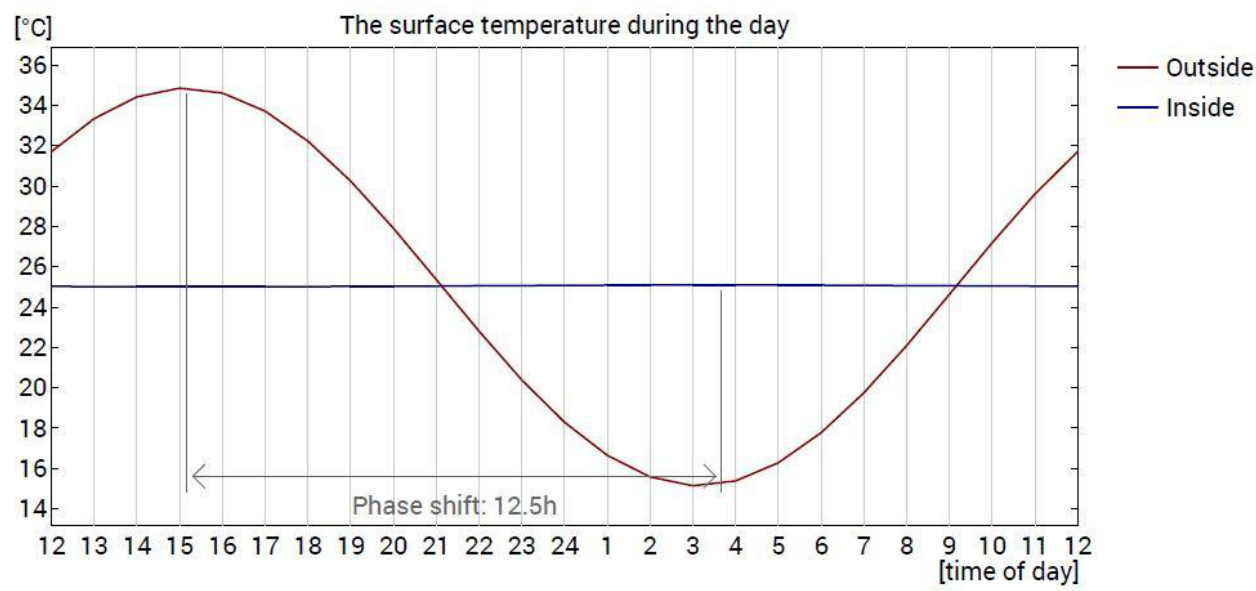

Fig. 15. The surface temperature during the day.

The report on thermal calculations of the third type of the wall (fig.16-19). 


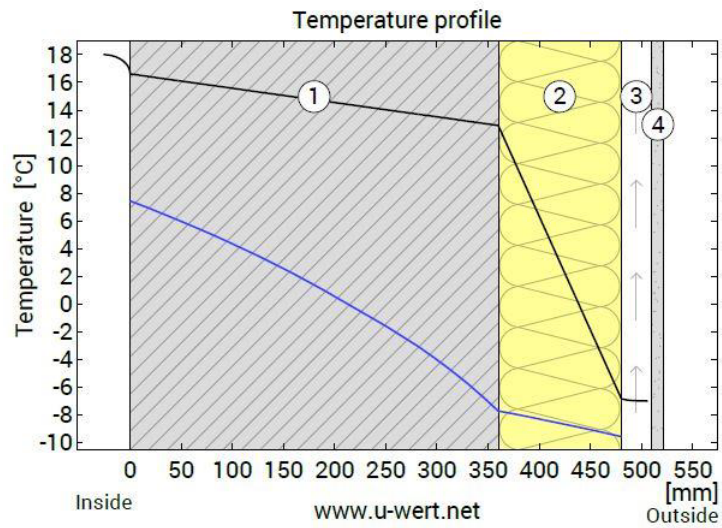

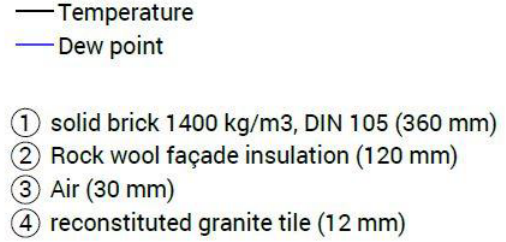

(1) solid brick $1400 \mathrm{~kg} / \mathrm{m} 3$, DIN $105(360 \mathrm{~mm})$

(2) Rock wool façade insulation $(120 \mathrm{~mm})$

(3) Air $(30 \mathrm{~mm})$

(4) reconstituted granite tile $(12 \mathrm{~mm})$

Fig. 16. Temperature gradient. Condensing zone.

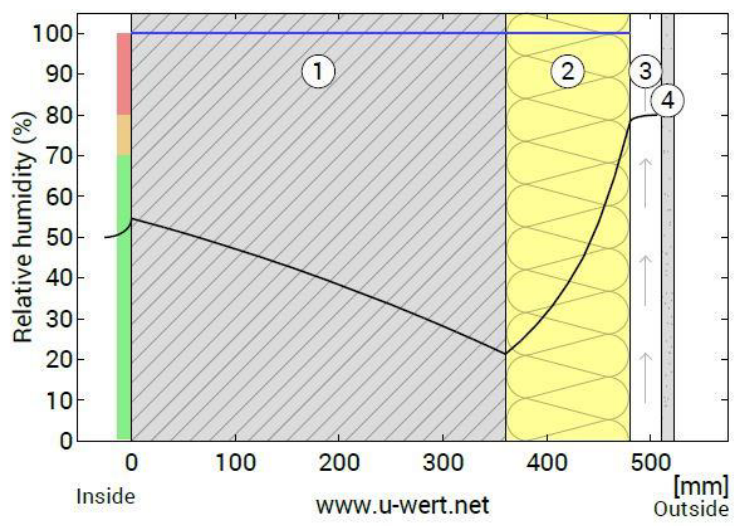
- Relative humidity (\%)
— saturation point
(1) solid brick $1400 \mathrm{~kg} / \mathrm{m} 3$, DIN 105 (360 mm)
(2) Rock wool façade insulation $(120 \mathrm{~mm})$
(3) Air $(30 \mathrm{~mm})$
(4) reconstituted granite tile $(12 \mathrm{~mm})$

Fig. 17. Humidity schedule.

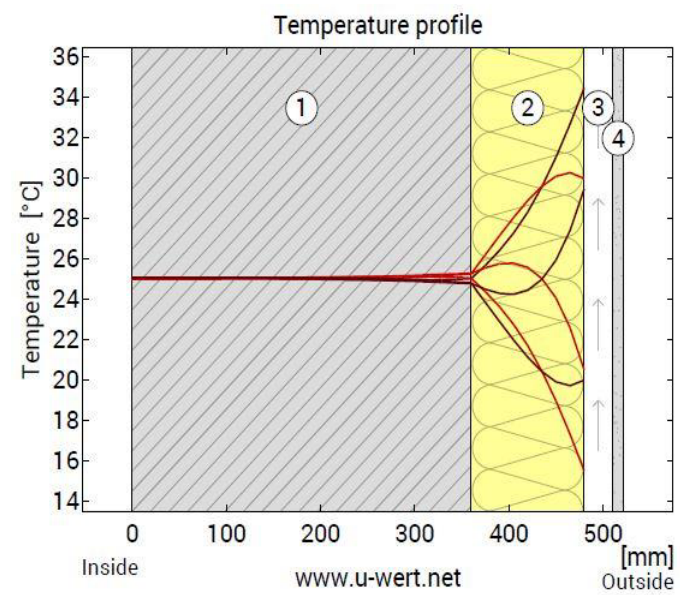

(1) solid brick $1400 \mathrm{~kg} / \mathrm{m} 3$, DIN $105(360 \mathrm{~mm})$

(2) Rock wool façade insulation $(120 \mathrm{~mm})$

(3) Air $(30 \mathrm{~mm})$

(4) reconstituted granite tile $(12 \mathrm{~mm})$

Fig. 18. Temperature schedule. 


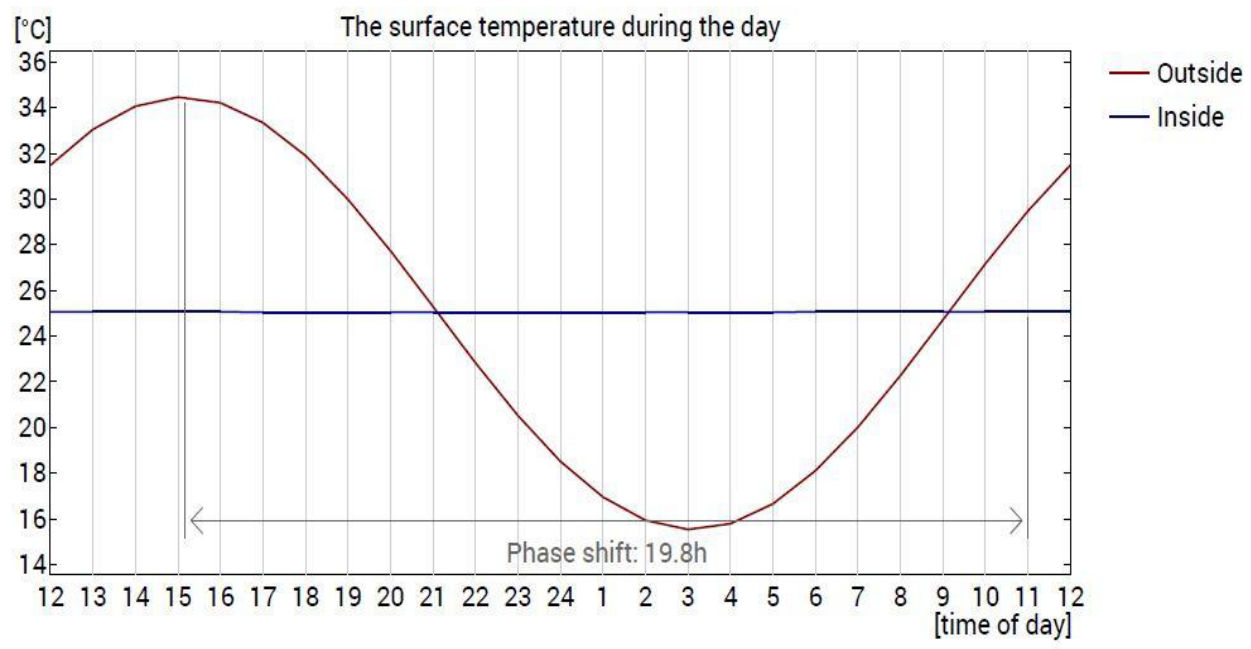

Fig. 19. The surface temperature during the day.

\section{Conclusion}

Buildings account for $40 \%$ of energy consumption in most countries, yet their potential for energy efficiency is huge. By using adapted insulation and energy savings techniques, up to $80 \%$ of a building's energy consumption for heating or cooling can be saved. In a building that is insufficiently or not insulated, heat flows through the roof or the façades thus leading to increased energy needs for heating (in winter) or for cooling (in summer).

According to the building inspection, we can make the following conclusions: The main heat leaks occur at the location of windows, doors and joints of window frames with walls, also joints of doors with floor and field installation of keyholes.

At purpose of identical the thermal transmission coefficient the most massive design is Type $1(665 \mathrm{~mm})$ after comparison of three types of the enclosure structures in the program U-value.net. In addition, the thinnest enclosure structure is Type $2(415 \mathrm{~mm})$. Therefore it brings influence to bear on architectural appearance and weight of the building in general that allows to reduce sections of the bearing designs and to reduce construction cost. By results of research the construction consisting of concrete $(250 \mathrm{~mm})$, Extruded polysterene $(150 \mathrm{~mm})$ and Gypsum Plaster $(15 \mathrm{~mm})$ is the most power effective type of an enclosure structure at this value of the thermal transmission coefficient $U=0.23$.

\section{References}

1. N. Vatin, D. Nemova, A. Kazimirova, K. Gureev, Advanced Materials Research, 15371544 (2014)

2. N. Vatin, A. Gorshkov, P. Rymkevich, D. Nemova, D. Tarasova, Applied Mechanics and Materials, 365-369 (2014)

3. N. Vatin, A. Gorshkov, D. Nemova, O. Gamayunova, D. Tarasova, Applied Mechanics and Materials, 349-354 (2014)

4. I. Marcov, Architecture and Modern Information Technologies, 1(18), 13-18 (2014)

5. Xinhong Zhaoa, Congyu Mab, Pingdao Gub, Energy Procedi, 1523-1527 (2012)

6. National Building Code of Finland

7. N. Vatin, O. Gamayunova, Applied Mechanics and Materials, 972-976 (2014) 
8. N. Vatin, A. Gorshkov, D. Nemova, A. Staritcyna, D. Tarasova, Advanced Materials Research, 905-920 (2014)

9. A. Pogonin, Architecture and Modern Information Technologies, 4 (13), 13 (2010)

10. A. Gorshkov, D. Nemova, N. Vatin, Construction of Unique Buildings and Structures, 7 (12), 49-63 (2013)

11. O. Averyanova, Magazine of Civil Engineering, 5, 53-59 (2011)

12. D. Nemova, V. Murgul, A. Golik, E. Chizhov, V. Pukhkal, N. Vatin, Journal of Applied Engineering Science, 12 (1), 37-44 (2014)

13. S. Ginestet, D. Marchio, O. Morisot, Energy Conversion and Management, 76, 368-376 (2013)

14. R. Alihodzic, V. Murgul, N. Vatin, E. Aronova, V. Nikolić, M. Tanić, D. Stanković, Applied Mechanics and Materials, 624, 604-612 (2014)

15. N. Vatin, O. Gamayunova, Advanced Materials Research, 2159-2162 (2015)

16. N. Vatin, A. Gorshkov, D. Nemova, A. Staritcyna, D. Tarasova, Advanced Materials Research, 905-920 (2014)

17. D. Nemova, V. Murgul, A. Golik, E. Chizhov, V. Pukhkal, N. Vatin, Journal of Applied Engineering Science, 12 (1), 37-44(2014)

18. N. Vatin, D. Nemova, L. Khazieva, D. Chernik, Applied Mechanics and Materials, 2057-2062 (2014)

19. N. Vatin, A. Gorshkov, D. Nemova, D. Tarasova, Mechanics and Materials, 991-996 (2014)

20. Y. Iwafune, K. Nishio, Journal of Environmental Engineering, 650, 371-379 (2010)

21. M. Bassanino, T. Fernando, J. Masior, M. Kadolsky, Fouchal R. Scherer, Fouchal, R., Firth, T. Hassan, K. Klobut, 10th European Conference on Product and Process Modellin, 863-870 (2015)

22. A. Gorshkov, Energosberezhenie, 4, 12-19 (2014)

23. M. Petrichenko, D. Nemova, A. Staritcyna, D. Tarasova, Applied Mechanics and Materials, 2308-2315 (2014)

24. N. Vatin, D. Nemova, D. Tarasova, A. Staritcyna, 3rd International Conference on Energy and Environmental Protection, 854-870 (2014)

25. N. Vatin, D. Nemova, L. Khazieva, D. Chernik, Applied Mechanics and Materials, 2057-2062 (2014)

26. K. Petrov, E. Zolotareva, V. Volodin, N. Vatin, E. Zhmarin, Magazine of Civil Engineering, 2, 59-64 (2010)

27. V. Murgul, Procedia Engineering, 117, 808-818 (2015)

28. V. Murgul, D. Vuksanovic, V. Pukhkal, N. Vatin, Applied Mechanics and Materials, 977-981 (2014) 